\title{
ACANTHACEAE: MENDONCIOIDEAE OF MEXICO
}

\author{
Thomas F. Daniel \\ Department of Botany \\ California Academy of Sciences \\ Golden Gate Park \\ San Francisco, CA 94118, U.S.A.
}

\begin{abstract}
Subfamily Mendoncioideae of the Acanthaceae is represented in Mexico by two species, Mendoncia guatemalensis and $M$. retusa. The former species is reported from Mexico for the first time. The initial description of flowers of $M$. guatemalensis is presented. A lectotype for $M$. retusa is designated. Both species are described and illustrated; a key is provided to distinguish them; and the distribution of each species in Mexico and northern Central America is shown on a map.
\end{abstract}

\section{RESUMEN}

La subfamilia Mendoncioideae de la familia Acanthaceae está representada en México por dos especies, Mendoncia guatemalensis y $M$. retusa. Se registra por primera vez para México Mendoncia guatemalensis, anteriormente conocida sólo de Guatemala, se encontró en las selvas cálido-húmedas de Veracruz y Oaxaca. También se presenta la primera descripción de las flores de esta especie. Mendoncia retusa se encuentra desde el sur de México (Chiapas) hasta Panamá. Se designa un lectotipo para M. retusa. Las dos especies se describen e ilustran; se presenta una clave para determinarlas, asi como datos acerca de su distribución y afinidades ecológicas.

Mendoncia Vell. ex Vand. is an anomalous genus of perennial vines occurring in the tropics of Africa, Madagascar, and America. The genus and its relatives have been variously classified among the Scrophulariales. Traditionally, they have constituted subfamily Mendoncioideae of the Acanthaceae (Lindau, 1895). This subfamily comprises Mendoncia and Anomacanthus R. Good (=Gilletiella De Wild. \& T. Durand). The latter genus consists of a single Africain species. Other paleotropical genera (i.e., Monachoclamys J. Baker and Afromendoncia Gilg.) that were included in the Mendoncioideae by Lindau (1895) are now included within Mendoncia. The Mendoncioideae are distinguishable from other Acanthaceae by their climbing habit and flesy, drupaceous fruits. The subfamily has been commonly allied to subfamily Thunbergioideae which also contains twining vines with large bracteoles and reduced calyces. Bremekamp (1953) treated both the Thunbergioideae and Mendoncioideae as distinct families more closely related to each other than to the residual Acanthaceae. Cronquist (1981) recognized the Mendonciaceae because its species lack both cystoliths and the specialized mechanism of seed dispersal that characterize the Acanthaceae. Although excluding the Mendoncioideae from the Acanthaceae results in the latter being more readily characterized by its fruit (i.e., an explosively dehiscent loculicidal capsule), Brummitt (1989) effectively argued for inclusion of the Mendoncioideae and Thunbergioideae within the Acanthaceae. Because Mendoncia and its relatives remain 
poorly collected and described, I prefer to follow tradition and Brummitt's argument by including the Mendoncioideae within the Acanthaceae at this time.

Turrill (1919) recognized 25 American species of Mendoncia in the most recent revision of the entire genus. Since his revision 38 species have been described in or transferred to the genus from Central and South America, tropical western Africa, and Madagascar. Most of the American species occur in South America (with concentrations of species in Brazil, northeastern South America, and the northern Andes). Wasshausen (1990) provided a key to 32 species in Colombia and the 15 Brazilian species were recently treated by Profice (1988, 1989). Ten species are currently recognized as occurring in Central America (Durkee, 1978, 1986; Gibson, 1974). Prior to this report, only a single species, $M$. retusa Turrill, was known from Mexico (Gibson, 1974). Mendoncia guatemalensis Standl. \& Steyermark has recently been collected from two localities in southern Mexico. Flowers from these collections are the first known for this species. Available information for the two species of Mendoncia in Mexico is summarized below.

Mendoncia Vell. ex Vand. FI. Lusit. Bras. 43. 1788.- Type: M. aspera Ruiz \& Pavon.

Herbaceous or suffrutescent twining (counterclockwise) vines, glabrous or pubescent with simple or stellate trichomes, cystoliths lacking. Leaves opposite, petiolate. Flowers solitary or clustered in leaf axils, each pedunculate and subtended by 2 large, flat or keeled, spathelike bracteoles (=bracts of some authors). Bracteoles green, variously shaped and vestured, often equaling corolla tube, valvate, often partially connivent or connate, remaining closed around flower, often widely spreading in fruit. Calyx inconspicuous, annular or cupular, entire to irregularly dentate or lobed. Corolla whitish, greenish, or reddish, often with purplish markings within, the tube cylindric to funnelform, the limb subequally 5 -lobed or bilabiate with the upper lip comprising 2 lobes and the lower lip comprising 3 lobes, the lobes spreading or reflexed. Stamens 4 , didynamous, included, the anthers dithecous with parallel, subequal to unequal thecae that are \pm pubescent at base, dehiscing longitudinally or by subapical pores or slits, the pollen spherical, 5-6-colpate; staminode, if present, 1, inconspicuous. Style filiform, the stigma shallowly and unequally bilobate. Fruit drupaceous, ovoid to ellipsoid, the mesocarp fleshy, the endocarp osseous. Seeds 1-2.

About 50-60 species from southern Mexico to southern Brazil, tropical western Africa, and Madagascar. Most workers have distinguished species primarily on the basis of vegetative and bracteolar characters.

Key to species of Mendoncia in México

1. Bracteoles 1.6-2.2 times longer than wide, abaxially evenly and \pm densely pubescent with conspicuous, antrorse to antrorse-appressed eglandular trichomes $0.4-1 \mathrm{~mm}$ long, rounded- to acute-apiculate at apex; drupe $18-23 \mathrm{~mm}$ long, 11-15 $\mathrm{mm}$ in diameter M. guatemalensis

1. Bracteoles 1.3-1.6 times longer than wide, abaxially glabrous, very sparsely pubescent with a few scattered antrorse-appressed eglandular trichomes $0.2-0.3 \mathrm{~mm}$ long, or puberulent with inconspicuous straight eglandular trichomes $0.05-0.1 \mathrm{~mm}$ long; retuseapiculate at apex; drupe 14-17 $\mathrm{mm}$ long, 7.5-10 $\mathrm{mm}$ in diameter M. retusa 
A species known from nearby regions of Belize and Guatemala, M. lindavii Rusby, might be expected to occur in Mexico as well. It can be distinguished from these two species by its lance-ovate, apically acuminate-falcate bracteoles covered with spreading, goldenbrown trichomes up to $4.5 \mathrm{~mm}$ long and by its reddish corolla.

Mendoncia guatemalensis Standley \& Steyermark, Publ. Field Mus. Nat. Hist., Bot. Ser. 23: 245. 1947.- Type: GUATEMALA. Huehuetenango: Sierra de los Cuchumatanes, between Ixcán and Río Ixcán, 23 July 1942, J. Steyermark 49270 (holotype: F!). Figures 1 and 2.

Perennial vine. Young stems quadrate to quadrate-sulcate, at first evenly and densely pubescent with antrorse-appressed, golden brown or straw-colored, eglandular trichomes 0.3-0.8 $\mathrm{mm}$ long, the trichomes of internodes soon becoming sparse. Leaves petiolate; petioles to $25 \mathrm{~mm}$ long; blades somewhat discolorous, darker green adaxially than abaxially, ovate-elliptic to elliptic to obovate-elliptic, $54-112 \mathrm{~mm}$ long, $25-83 \mathrm{~mm}$ wide, 1.3-2.2 times longer than wide, rounded to acute at base, acute-apiculate to subacuminate at apex, surfaces pubescent with antrorse to antrorse-appressed eglandular trichomes (often restricted to major veins on adaxial surface), margin entire, sometimes undulate. Inflorescences axillary, solitary or paired at nodes; flowers 1-2 per axil, borne on peduncles to $22 \mathrm{~mm}$ long; peduncles pubescent like stem. Bracteoles elliptic to ovate-elliptic, 20-29 $\mathrm{mm}$ long, $10-18 \mathrm{~mm}$ wide, 1.6-2.2 times longer than wide, abaxially pubescent with antrorse to antrorse-appressed eglandular trichomes $0.4-1 \mathrm{~mm}$ long, adaxially glabrous to somewhat mealy-glandular, rounded- to acute-apiculate at apex, ciliate with antrorse-flexuose eglandular trichomes to $1.3 \mathrm{~mm}$ long and connate when young at margins. Calyx a small, rigid, entire, often undulating, annular or cupular ring, $1.5-2 \mathrm{~mm}$ long. Corolla white with purple internally, $42 \mathrm{~mm}$ long, externally glabrous; tube $24 \mathrm{~mm}$ long, apically ampliate; limb $16 \mathrm{~mm}$ in diameter, the upper lip $6 \mathrm{~mm}$ long with rounded lobes $4 \mathrm{~mm}$ long, $5-7 \mathrm{~mm}$ wide, the lower lip $18 \mathrm{~mm}$ long with rounded lobes $5-8 \mathrm{~mm}$ long, 5-6.5 mm wide. Stamens 10$11 \mathrm{~mm}$ long, inserted near middle of corolla tube, the ventral pair inserted $1-2 \mathrm{~mm}$ distal to dorsal pair; filaments short, intergrading with connective; thecae 6-7.5 mm long, each opening by a short apical slit or pore, densely pubescent at base with a tuft of stout eglandular trichomes; connective projecting $2-3 \mathrm{~mm}$ beyond thecae, attenuate, pubescent with glandular and eglandular trichomes $0.05-0.2 \mathrm{~mm}$ long; staminode consisting of a glabrous projection $1.3 \mathrm{~mm}$ long. Disc annular or cupular, $2 \mathrm{~mm}$ high. Style $22-23 \mathrm{~mm}$ long; stigma subequally bilobed with lobes $0.5-1 \mathrm{~mm}$ long. Drupe grenish yellow (immature) becoming blackish or purplish (mature), subellipsoid, 18-23 mm long, 11-15 mm in diameter, surface mealy-glandular.

Distribution and habitat. Southern Mexico (Veracruz and Oaxaca) and Guatemala (Fig. 3); plants occur in regions of lower montane rain forest at elevations from 200 to 400 meters.

Phenology. Flowering: April; fruiting: June-September.

Additional specimens examined. MEXICO. Oaxaca: mpio. Sta. María Chimalapa, Cerro Azul-Escolapa, ca. 7 km SO de Sta. María, 1652'N, 94943'W, H. Hernández G. 
238 (CAS); mpio. Sta. Maria Chimalapa, ca. $8 \mathrm{~km} \mathrm{~N}$ de Sta. Maria, $16^{\circ} 57^{\prime} \mathrm{N}, 94^{\circ} 41^{\prime} \mathrm{W}$, H. Hernández G. 1140 (CAS); mpio. Sta. María Chimalapa, región del Río Verde, ca. 810 km N de Sta. María, 1700'N, 94²41'W, H. Hernández G. 1229 (CAS). Veracruz: mpio. Catemaco, 8 km al SE de El Bastonal, R. Cedillo T. 3419 (CAS).

This species was previously known only from the type, a fruiting specimen wich was collected in western Guatemala. The description above provides the first information on flowers for $M$. guatemalensis. Both occurrences of the plant in Mexico are from regions of lower montane rain forest. It is likely that this species will eventually be found in similar habitats of Chiapas which lie between the type locality in Guatemala and known occurrences in Oaxaca and Veracruz.

Mendoncia retusa Turrill, Kew Bull. 1919: 423. 1919.- Type: PANAMA. Manmee Station, 30 September 1861, S. Hayes 169 (lectotype: K!, designated here; isolectotype: BM!). Figures 1 and 2.

Perennial vine. Young stems quadrate with angles often minutely winged, at first evenly pubescent with antrorse to antrorse-appressed eglandular trichomes $0.2-0.5 \mathrm{~mm}$ long, the internodes soon mostly glabrate. Leaves petiolate; petioles to $38 \mathrm{~mm}$ long; blades ovate to elliptic, $67-105 \mathrm{~mm}$ long, $32-55 \mathrm{~mm}$ wide, 1.9-2.6 times longer than wide, rounded to acute at base, acute-apiculate to acuminate at apex, surfaces pubescent with cauline type trichomes, the trichomes sparse and mostly restricted to major veins at maturity, margin entire, sometimes undulate. Inflorescences axillary, solitary or paired at nodes; flowers 1 per axil, borne on peduncles to $35 \mathrm{~mm}$ long; peduncles sparsely pubescent with cauline type trichomes or nearly glabrous. Bracteoles ovate to elliptic, 17-30 mm long, 11$18 \mathrm{~mm}$ wide, 1.3-1.6 times longer than wide, abaxially glabrous or nearly so (i.e., with a few scattered antrorse-appressed eglandular trichomes $0.2-0.3 \mathrm{~mm}$ long) or puberulent (i.e., with inconspicuous straight eglandular trichomes $0.05-0.1 \mathrm{~mm}$ long), adaxially mealyglandular, retuse-apiculate at apex, ciliate with antrorse-appressed eglandular trichomes 0.2-0.5 mm long and connivent when young at margins. Calyx a small, rigid, entire, often flaring, annular or cupular ring, $1-1.5 \mathrm{~mm}$ long. Corolla white with purplish markings internally, 35-55 mm long, externally glabrous; tube 35-39 mm long, apically ampliate; limb 21-27 mm in diameter, the upper lip $8 \mathrm{~mm}$ long with rounded lobes $7 \mathrm{~mm}$ long, $6.5 \mathrm{~mm}$ wide, the lower lip $11 \mathrm{~mm}$ long with rounded lobes $9.5 \mathrm{~mm}$ long, $7.5 \mathrm{~mm}$ wide. Stamens 10-12 mm long, inserted near midpoint of corolla tube; filaments short, intergrading with connective; thecae 7.5-8.5 mm long, each opening by a short apical slit or pore, densely pubescent at base with a tuft of stout eglandular trichomes; connective projecting $1.2 \mathrm{~mm}$ beyond thecae, triangular, very sparsely pubescent with glandular trichomes $0.1 \mathrm{~mm}$ long or glabrate; staminode not seen. Disc annular or cupular, $1 \mathrm{~mm}$ high. Style 30-35 mm long; stigma subequally bilobed with lobes $0.8-1.6 \mathrm{~mm}$ long. Drupe greenish turning blackish purple when mature, obliquely ellipsoid, $14-17 \mathrm{~mm}$ long, $7.5-10 \mathrm{~mm}$ in diameter, surface minutely mealy-glandular.

Distribution and habitat. Southern Mexico (Chiapas, Fig. 3), Guatemala, Belize, Honduras, Nicaragua, Costa Rica, and Panama; in Mexico, plants occur in a region 


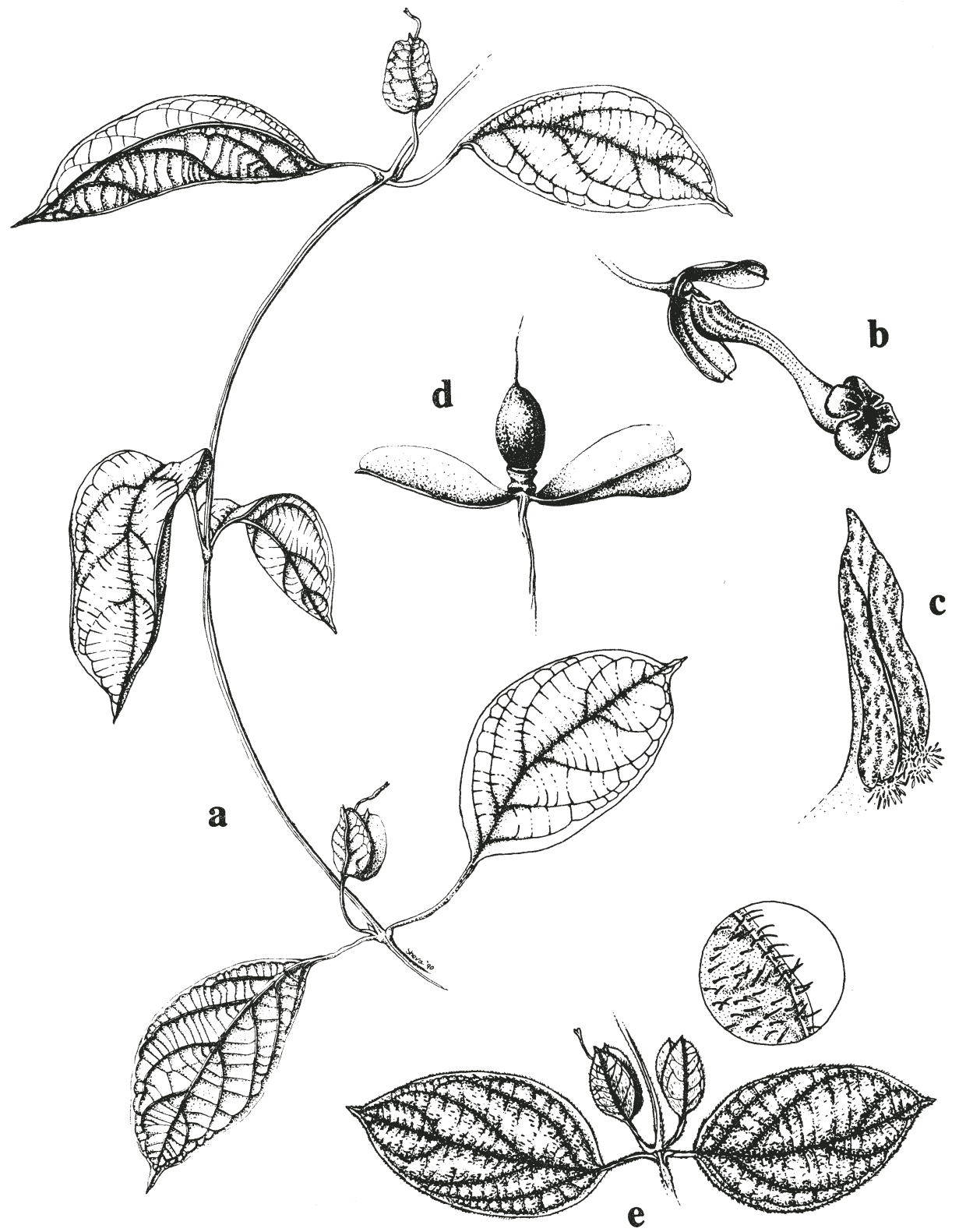

Fig. 1. Mendoncia retusa (a-d) and M. guatemalensis (e). a. Habit (Breedlove \& Thorne 30707) X 0.4; b. Inflorescence with bracteoles opened to show base of flower (Lankester 952) X 0.7; c. Fruit (Daniel et al. 5477) X 0.7; d. Anther (Lankester 952) X 3.8; e. Node (Hernández G. 1229) X 0.4, with enlargement (X 2.5) of abaxial surface of bracteole. 

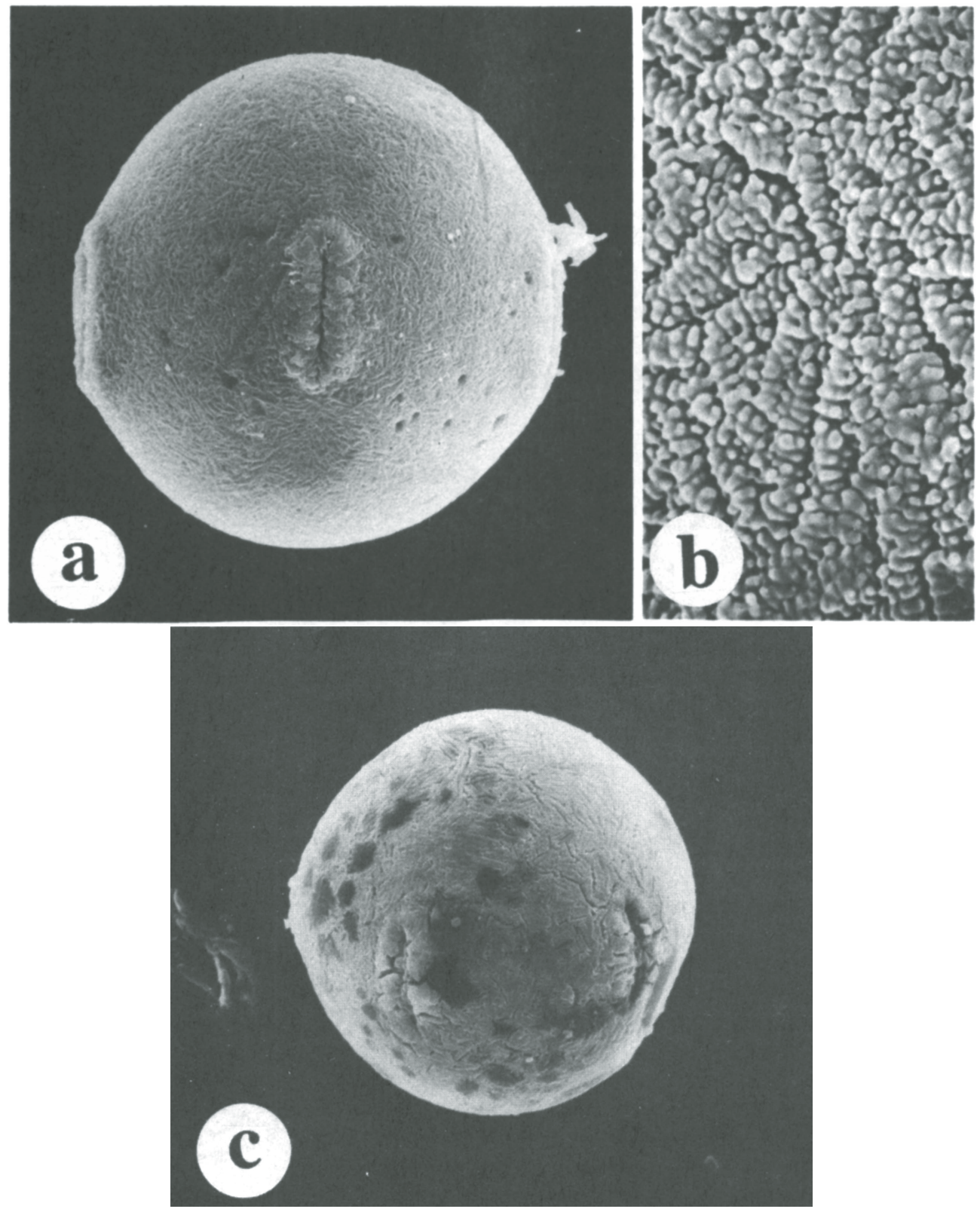

Fig. 2. Pollen of Mexican Mendoncia. a. M. retusa (Matuda 16603), equatorial view, X 1200; b. M. retusa (Matuda 16603 ), surface, X 10,000; c. M. guatemalensis (Hernández G. 1140), subequatorial view, X 1200. 
transitional between rain forest and tropical deciduous forest ("Evergreen Seasonal Forest" of Breedlove, 1981) at elevations from 180 to 500 meters on the Pacific coastal plain of Chiapas.

Phenology. Flowering: July-December; fruiting: February-May, SeptemberDecember.

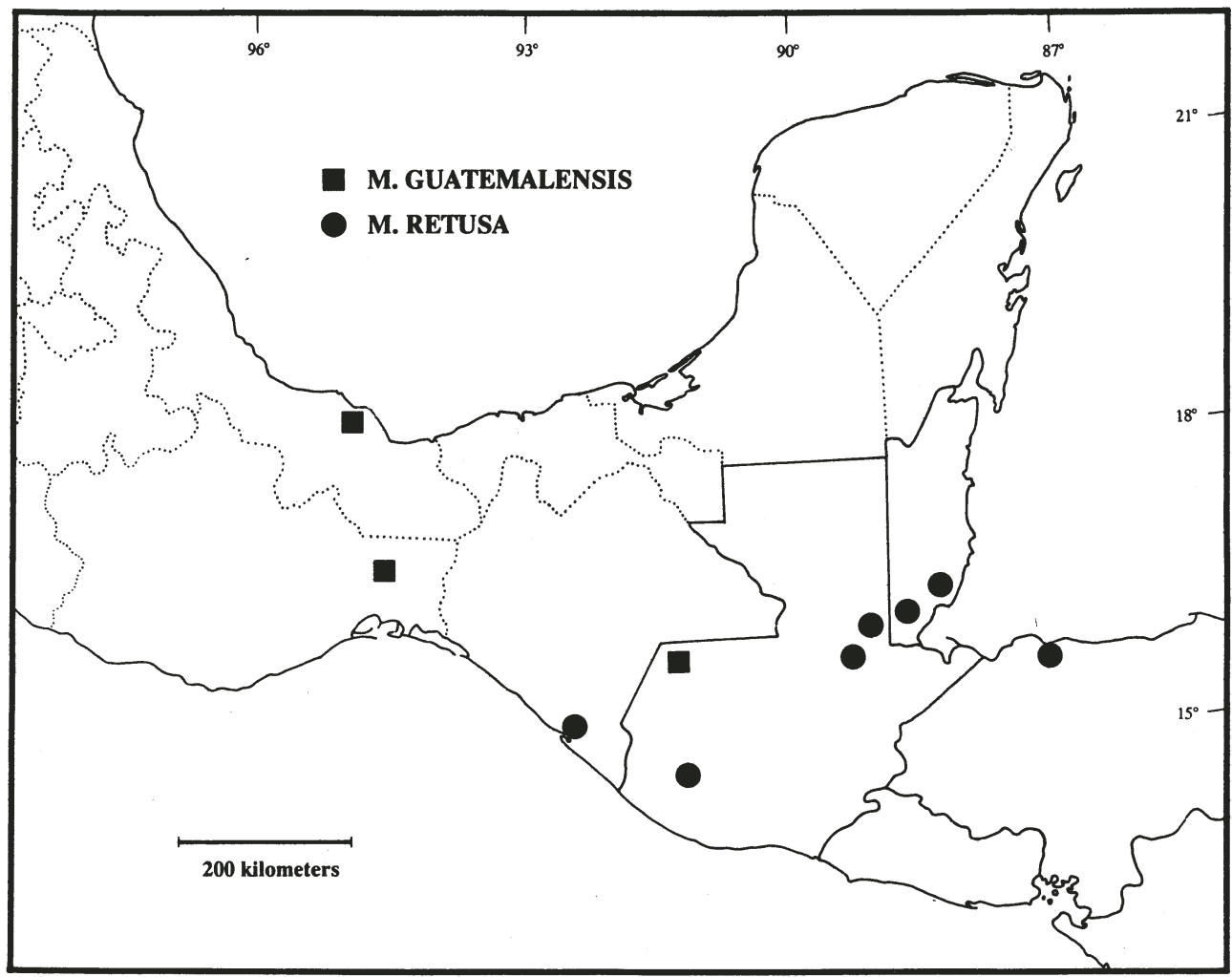

Fig. 3. Distribution of Mendoncia guatemalensis and M. retusa in Mexico and northern Central America. 
Local names. "Tapita" (Matuda 16603 ), "tapia" (Matuda 17300).

Additional specimens examined. MEXICO. Chiapas: mpio. Mapastepec, along Río Testecapa $10 \mathrm{~km}$ SE of Mapastepec, D. Breedlove \& R. Thorne 30707 (DS); Esperanza, Escuintla, E. Matuda 16603 (F, K, USJ), 17300 (F); Libertad, Acacoyagua, E. Matuda 18142 (DS, F).

In the protologue two syntypes (Hayes 169 from Panama and Tate 291 from Nicaragua) were cited. Both are extant at $\mathrm{K}$ and conform to the protologue equally well. The former syntype, which has more bracteoles, is selected as the lectotype.

Flowering collections of $M$. retusa are not common. Some measurements for floral organs in the above description were obtained from Central American plants.

\section{ACKNOWLEDGMENTS}

I am grateful for the assitance of the following persons: Sheva Hill who prepared the line drawing; Lisa Borok who supervised operation of the scanning electron microscope; Nancy Hensold who provided locality information; and the curators of the herbaria cited in the text who provided loans or opportunities for visits to their institutions.

\section{LITERATURE CITED}

Breedlove, D. 1981. Introduction to the flora of Chiapas. In: Breedlove, D. Flora of Chiapas 1. California Academy of Sciences. $35 \mathrm{pp}$.

Bremekamp, C. 1953. The delimitation of the Acanthaceae. Proc. Nederl. Akad. Wet. C. 56: 533-546.

Brummitt, R. 1989. Against separating Mendonciaceae from Acanthaceae. Acanthus 5: 1-3.

Cronquist, A. 1981. An integrated system of classification of flowering plants. Columbia University Press, New York. $1262 \mathrm{pp}$.

Durkee, L. 1978. Acanthaceae. In: Woodson, R. and R. Schery. Flora of Panama. Ann. Missouri Bot. Gard. 65: $155-284$.

Durkee, L. 1986. Acanthaceae. In: Burger, W. Flora Costaricensis. Fieldiana, Bot. 18: 1-87.

Gibson, D. 1974. Acanthaceae. In: Standley, P. et al. Flora of Guatemala. Fieldiana, Bot. 24(10): 328461.

Lindau, G. 1895. Acanthaceae. In: Engler, A. and K. Prantl. Die Natürlichen Pflanzenfamilien IV(3b): 274354.

Profice, S. 1988. Mendoncia rizziniana (Acanthaceae) espécie nova do estado do Acre. Revista Brasil. Biol. 48: 397-399.

Profice, S. 1989 (1988). Mendoncia Vell. ex Vand. (Acanthaceae) espécies ocorrentes no Brasil. Arch. Jard. Bot. Rio de Janeiro 29: 201-279.

Turrill, W. 1919. A revision of the genus Mendoncia. Bull. Misc. Inform. 1919: 407-425.

Wasshausen, D. 1989. New species of Mendoncia (Acanthaceae) from Colombia. Brittonia 41: 329-334. 